\title{
Cellular Physiology

\section{Intratracheal Instillation of Lipopolymeric Vectors and the Effect on Mice Lung Physiology}

\author{
Debora G. Xisto ${ }^{1,2}$, Carlos Facundo Temprana ${ }^{3}$, Sabrina V. Martini²,
} Adriana L. Silva ${ }^{1}$, Soraia G. Abreu ${ }^{1}$, Johnatas D. Silva ${ }^{1}$, Julia Crosseti ${ }^{1}$, Patricia R. M. Rocco ${ }^{1}$, Silvia del Valle Alonso ${ }^{3}$ and Marcelo M. Morales ${ }^{2}$

${ }^{1}$ Laboratory of Pulmonary Investigation, ${ }^{2}$ Laboratory of Cellular and Molecular Physiology, Carlos Chagas Filho Institute of Biophysics, Federal University of Rio de Janeiro, Rio de Janeiro, ${ }^{3}$ Biomembrane Laboratory, Departamento de Ciencia y Tecnología, Universidad Nacional de Quilmes, Buenos Aires

\author{
Key Words \\ Lipopolymers • Mice • Lung • Mechanics • Gene \\ therapy
}

\begin{abstract}
Background/Aims: The current study compared the effects of intratracheal administration of different lipopolymeric vectors on lung function and histology in normal mice. Methods: Forty-eight BALB/c mice were randomly divided into 8 groups (6/group). All animals received intratracheal instillation of the following suspensions: polymerized [(A) 1,2-dimyristoyl-sn-glycero-3-phosphocholine (DMPC):1,2-bis-(tricosa-10,12-diynoyl)-sn-glycero3-phosphocholine (DC8,9PC):1,2-dioleoyl3-trimethylammonium-propane (DOTAP), (B) DMPC:DC8,9PC:stearylamine (SA), (C) DMPC:DC8,9PC:myristoylcholine chloride (MCI)]; nonpolymerized [(D) DMPC:DC8,9PC:DOTAP, (E) DMPC:DC8,9PC:SA, (F) DMPC:DC8,9PC:MCl] together with plasmid DNA; vehicle (control), and pDsRed2-N1 plasmid DNA (DNA). At $24 \mathrm{~h}$, the survival rate, lung mechanics (resistive and viscoelastic pressure, static elastance) and morphometry were analyzed. Results: The survival rate was $50 \%$ in $D$,
\end{abstract}

\section{KARGER}

Fax +41613061234

E-Mail karger@karger.ch

www.karger.com
(C) 2012 S. Karger AG, Basel

$1015-8987 / 12 / 0296-0791 \$ 38.00 / 0$

Accessible online at:

www.karger.com/cpb
$40 \%$ in $E$ and $F$, and $100 \%$ in the CTRL, DNA, A, B and $C$ groups. Animals from groups $D, E$, and $F$ that died presented diffuse pulmonary hemorrhagic capillaritis. Lung mechanics, the fraction of normal and collapsed alveoli, as well as the number of polymorphonuclear and mononuclear cells in lung tissue were similar in all surviving mice. Conclusion: Intratracheal instillation of polymerized particles is safe compared with nonpolymerized formulations and may be used for future gene/drug therapy.

Copyright @ 2012 S. Karger AG, Basel

\section{Introduction}

Respiratory diseases are very common worldwide and affect a large population. New therapy strategies, such as gene therapy, have being developed for acute and chronic lung diseases. In respiratory system gene therapy, the common gene carriers (viral and nonviral vetors) must deliver the therapeutic gene to the lung cells efficiently and overcome barriers such as the lung architecture, pulmonary defense mechanisms and the presence of mucus [1].

Marcelo Marcos Morales, MD, PhD,

Universidade Federal do Rio de Janeiro, Instituto de Biofísica Carlos Chagas Filho - C.C.S., Laboratório de Fisiologia Celular e Molecular, Ilha do Fundão 21941-902 - Rio de Janeiro - RJ (Brazil)

Tel. +55212562 6572, Fax +552122808193, E-Mail mmorales@biof.ufrj.br 
Nonviral vectors such as lipopolymeric agents have been considered as an alternative to viral vectors because they are less toxic, are easier to produce at low cost, and do not generate a specific immune response [2, 3]. Conversely, nonviral vectors are less stable in vivo and have low transfection efficiency.

The mechanism of gene delivery using lipopolymeric vehicles involves the following steps: the vectors bind to the cell surface by nonspecific, electrostatic interactions between the positively charged complexes and the negatively charged cell surface; vectors enter the cells by endocytosis or endocytosis-like mechanisms allowing the release of plasmid DNA in the cytosol; vectors enter the nucleus by passive DNA entry during cell division, when the nuclear membrane disintegrates temporarily, or by active transport of the DNA through nuclear pores [4]. DNA complexes must overcome a series of barriers to gain access to the membrane surface, cytoplasmic compartment, and nucleus of a target cell, and to translate transgene into protein. As particles encounter each of these barriers, they are subject to a certain probability of success or failure in overcoming each barrier to ensure transfer of the gene [5].

Among the different delivery systems, liposomes, composed of photopolymerizable lipid 1,2-bis-(tricosa10,12-diynoyl)-sn-glycero-3-phosphocholine (DC8,9PC), have proved to be highly stable in different media compared with the same nonpolymerized formulation, without developing cell toxicity after the polymerization process $[6,7]$.

In the present study, we evaluate if lipopolymeric systems developed by our group cause an inflammatory response and lung injury and demonstrate if these vectors are able to delivery DNA to the lungs. For this purpose, we analyzed the impact of intratracheal instillation of 3 different liposome formulations on lung mechanics and histology, including the photopolymerizable lipid DC8,9PC, the saturated lipid 1,2-dimyristoyl-sn-glycero3-phosphocholine (DMPC), and the cationic lipids (CL) 1,2-dioleoyl-3-trimethylammonium-propane (DOTAP), stearylamine (SA), or myristoylcholine chloride (MCL) in a final 1:1:0.2 (DMPC:DC8,9PC:CL) molar ratio.

\section{Materials and Methods}

\section{Liposome preparation}

Polymerizable lipid DC8,9PC was obtained from Avanti Polar Lipids Inc. (Alabaster, AL, USA) and DMPC from Lipoid GmbH (Ludwigshafen, Germany). DOTAP and MCL were purchased from Toronto Research Chemicals Inc. (Ontario,
Canada), and SA from Fluka (Buchs, Switzerland).

Liposomes were prepared according to Bangham et al. [8]. Briefly, lipids were dissolved in chloroform in a 1:1:0.2 molar ratio of DMPC:DC8,9PC:CL; the solvent was evaporated until a thin dry film was obtained. The film was flushed and evaporated with nitrogen until there was no residual chloroform and then suspended in distilled water. The suspension was extruded 15 times at $50{ }^{\circ} \mathrm{C}$ through $0.2 \mu \mathrm{m}$ pore polycarbonate membranes, using a Mini Extruder from Avanti Polar Lipids, Inc.

\section{Extruded vesicle polymerization}

Diacetylenic vesicles were polymerized under $254 \mathrm{~nm}$ ultraviolet (UV) light (20 cycles of $360 \mathrm{~mJ} / \mathrm{cm}^{2}$ each), using a UV-Stratalinker 1800 , Stratagene ${ }^{\circledR}$. Temperature was maintained at $4{ }^{\circ} \mathrm{C}$ for $5 \mathrm{~min}$ between cycles.

\section{UV-vis spectrophotometry}

The polymerization process was evaluated by measuring the absorbance in the UV-visible (UV-vis) region after 20 polymerization cycles [7, 9-11]. The UV-vis absorption profile of the different samples was analyzed using a Nanodrop ND100 spectrophotometer (Thermo Scientific) with a $1-\mathrm{mM}$ final lipid concentration in the range of 400-700 $\mathrm{nm}$. Lipid concentration was determined by a phosphate assay, accordding to Bartlet's method [12].

\section{Light scattering}

We determined the size of lipopolymers at $25{ }^{\circ} \mathrm{C}$ by measuring the autocorrelation function at a scattering angle of $90^{\circ}$ in the 90 Plus/Bi-MAS Particle Size Analyzer (Brookhaven Instruments Corporation) instrument, with a light source of $632.8 \mathrm{~nm}$ and a laser power of $10 \mathrm{~mW}$. Acquisition and data analysis were performed using the software provided by the equipment manufacturer (Brookhaven 90Plus Particle Sizing Instruments Software).

\section{DNA purification}

Plasmid DNA pDsRed2-N1 (4692 bp) (Clontech, CA, USA) was purified from Escherichia coli hosts using a Wizard ${ }^{\circledR}$ Plus Midipreps DNA purification system from Promega, following the instructions provided by the manufacturer. DNA concentration (absorbance at $260 \mathrm{~nm}\left(A_{260}\right)$ ) was determined using a Nanodrop ND-100 spectrophotometer (Thermo Scientific). All DNA used in this work presented an $A_{260} / A_{280}$ ratio higher than 1.75 .

\section{Liposome/DNA complexes preparation}

Liposomes, whether polymerized or not, were incubated with plasmid DNA in a 16:1 ratio (moles of total lipid/moles of DNA base pairs). Briefly, plasmid DNA was mixed with the amount of liposomes necessary to get a 16:1 ratio in water and complex formation was allowed to occur for $30 \mathrm{~min}$ at $37{ }^{\circ} \mathrm{C}$ before use.

\section{Animal preparation and experimental protocol}

This study was approved by the Ethics Committee of the Carlos Chagas Filho Institute of Biophysics, Health Sciences

Xisto/Temprana/Martini/Silva/Abreu/Silva/Crosseti/Rocco/del Valle Alonso/Morales 
Centre, Federal University of Rio de Janeiro. All animals received humane care in compliance with the Principles of Laboratory Animal Care formulated by the National Society for Medical Research and the Guide for the Care and Use of Laboratory Animals prepared by the National Academy of Sciences, USA.

Forty-eight female BALB/c mice (20-25 g) were randomly assigned to 8 groups ( $n=6 /$ group). In the control group (CTRL), $50 \mu 1$ of vehicle were instilled intratracheally. In DNA Group animals were instilled with plasmid DNA $(9 \mu \mathrm{g}$ per dose $)$ in $50 \mu \mathrm{l}$ of vehicle. Groups A, B, C, D, E, and F with plasmid DNA ( $9 \mu \mathrm{g}$ per dose) received $50 \mu 1$ of $5 \mathrm{mM}$ (total lipid concentration) of the following suspensions: polymerized: (A) DMPC:DC8,9PC:DOTAP (1:1:0.2), (B) DMPC:DC8,9PC:SA (1:1:0.2), (C) DMPC:DC8,9PC:MCl(1:1:0.2); nonpolymerized:(D) DMPC:DC8,9PC:DOTAP (1:1:0.2), (E) DMPC:DC8,9PC:SA (1:1:0.2), (F) DMPC:DC8,9PC:MCl (1:1:0.2).

Mice were anesthetized with sevoflurane, a 1-cm-long midline cervical incision was made to expose the trachea, and either microparticle or vehicle was intratracheally instilled with a microsprayer (intratracheal aerosolizer, IA-1C S/M-551 Model, Penn-Century, Inc., Philadelphia, PA, USA) attached to a FMJ-250 high-pressure syringe (Penn-Century, Inc., Philadelphia, PA, USA). The cervical incision was closed with 5.0 silk suture and the mice were returned to their cage. Animals recovered rapidly after surgery.

\section{Mechanical parameters}

Twenty-four hours after the intratracheal instillation, animals were sedated (diazepam $1 \mathrm{mg}$ intraperitoneally (ip), anesthetized (thiopental sodium $20 \mathrm{mg} / \mathrm{kg} \mathrm{ip}$ ), tracheotomized, paralyzed (vecuronium bromide, $0.005 \mathrm{mg} / \mathrm{kg}$ intravenously), and ventilated with a constant flow ventilator (Samay VR15; Universidad de la República, Montevideo, Uruguay) with the following parameters: frequency of 100 breaths/min, tidal volume $\left(V_{\mathrm{T}}\right)$ of $0.2 \mathrm{ml}$, and fraction of inspired oxygen of 0.21 . The anterior chest wall was surgically removed and a positive end-expiratory pressure of $2 \mathrm{cmH}_{2} \mathrm{O}$ applied. Airflow and tracheal pressure $\left(P_{\text {tr }}\right)$ were measured [13]. Lung mechanics were analyzed by the end-inflation occlusion method [14]. In an open chest preparation, $P_{\mathrm{tr}}$ reflects transpulmonary pressure $\left(P_{\mathrm{L}}\right)$. Briefly, after end-inspiratory occlusion, there is an initial fast drop in $P_{\mathrm{L}}\left(\Delta P_{1}\right)$ from the preocclusion value down to an inflection point $\left(P_{\mathrm{i}}\right)$, followed by low pressure decay $\left(\Delta P_{2}\right)$, until a plateau is reached. This plateau corresponds to the elastic recoil pressure of the lung $\left(P_{\mathrm{e}}\right) . \Delta P_{1}$ selectively reflects the pressure used to overcome the airway resistance. $\Delta P_{2}$ reproduces the pressure spent by stress relaxation, or viscoelastic properties of the lung, together with a small contribution of pendelluft. Static lung elastance $\left(E_{\mathrm{st}}\right)$ was determined by dividing $P_{\mathrm{el}}$ by $V_{\mathrm{T}}$. Lung mechanics measurements were performed 10 times in each animal. All data were analyzed using ANADAT data analysis software (RHTInfoData, Inc., Montreal, Quebec, Canada).

\section{Lung histology}

A laparotomy was done immediately after the determination of lung mechanics and heparin (1000 IU) was

The Impact of Lipopolymeric Vectors on Lung Morphofunction intravenously injected into the vena cava. The trachea was clamped at end-expiration, and the abdominal aorta and vena cava were sectioned, yielding a massive hemorrhage that quickly killed the animals. The right lung was then removed, fixed in 3\% buffered formaldehyde and embedded in paraffin. Slices were cut $(4-\mu \mathrm{m}$ thick) and stained with hematoxylin-eosin. Lung histology analysis was performed with an integrating eyepiece with a coherent system consisting of a grid with 100 points and 50 lines (known length) coupled to a conventional light microscope (Olympus BX51, Olympus Latin America-Inc., Brazil). The volume fraction of collapsed and normal pulmonary areas and the number of mononuclear and polymorphonuclear cells in pulmonary tissue was determined using the point-counting technique $[15,16]$ across 10 random, non-coincident microscopic fields $[13,17]$.

DNA extraction and real-time polymerase chain reaction DNA extraction was performed using QIAamp ${ }^{\circledR}$ DNA Mini and Blood Mini Kit (Qiagen, GmbH, Hilden, Germany) to detect the plasmid DNA from lung tissue. Central slices of left lungs were cut, collected in cryotubes, quick frozen by immersion in liquid nitrogen, and stored at $-80{ }^{\circ} \mathrm{C}$. Polymerase chain reaction (PCR) primer for the target genes were purchased (Invitrogen, Carlsbad, CA). The following primers were used: DsRed 5'-CCC TAC GAG GGC CAC AAC AC-3' (forward) and 5'-GTG GAT CTC GCC CTT CAG CAC-3' (reverse), acidic ribosomal phosphoprotein P0 (36B4) 5'-CAA CCC AGC TCT GGA GAA AC-3' (forward) and 5'-GTT CTG AGC TGG CAC AGT GA-3' (reverse), used as reference gene. Relative DNA levels were measured with a SYBR green detection system using ABI 7500 real-time PCR (Applied Biosystems, Foster City, CA). All samples were measured in triplicate

\section{Statistical analysis}

Normality of the data was tested using the KolmogorovSmirnov test with Lilliefors' correction. The Levene median test was used to evaluate the homogeneity of variances. The effects of lung mechanics and morphometry were assessed using one-way analysis of variance followed by the Tukey post-hoc test. All data are expressed as mean \pm SEM. All tests were performed using the SigmaStat 3.1 statistical software package (Jandel Corporation, San Raphael, CA, USA). Significance was established at $p<0.05$.

\section{Results and Discussion}

To better understand this study we divided it into two steps: (1) characterization of the different lipopolymeric vectors; and (2) analysis of lung function and inflammation, and the DNA delivery in animals instilled intratracheally with different the liposome/DNA complexes under study.

In the first step, we tested liposomal systems composed of polymerizable DC $8,9 \mathrm{PC}$ and saturated 


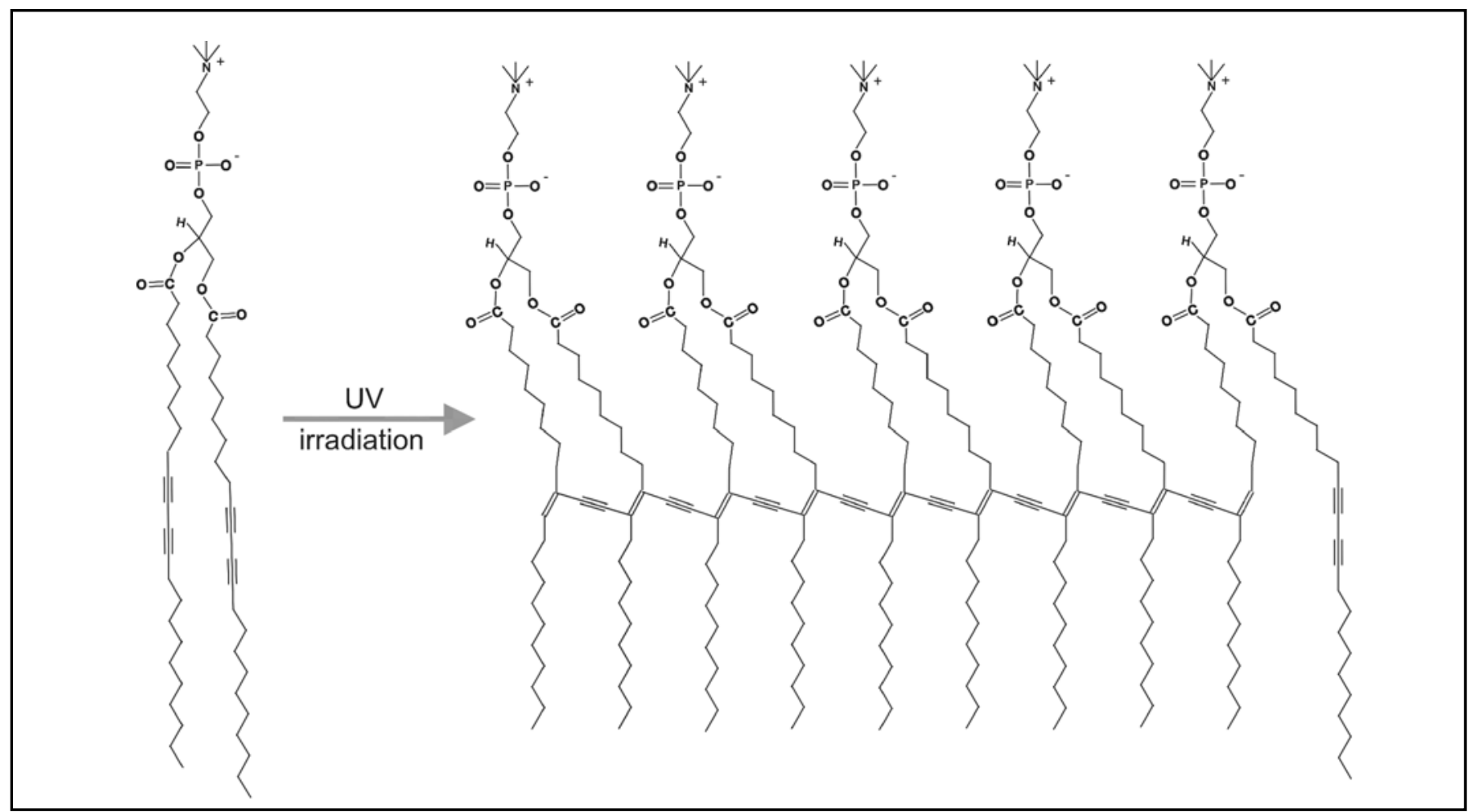

Fig. 1. Polymerization scheme for DC8,9PC molecules.

\begin{tabular}{llccc}
\hline Formulation & $\begin{array}{c}\text { Maximum 1 } \\
(\mathrm{nm})\end{array}$ & $\begin{array}{c}\text { Polymeric } \\
\text { units }\end{array}$ & $\begin{array}{c}\text { Maximum 2 } \\
(\mathrm{nm})\end{array}$ & $\begin{array}{c}\text { Polymeric } \\
\text { units }\end{array}$ \\
\hline DMPC:DC ${ }_{8,9}$ PC:DOTAP $(1: 1: 0.2)$ & 524 & 9.1 & 483 & 5.8 \\
DMPC:DC ${ }_{8,9}$ PC:SA (1:1:0.2) & 520 & 8.7 & 480 & 5.6 \\
DMPC:DC ${ }_{8,9}$ PC:MCL $(1: 1: 0.2)$ & 520 & 8.7 & 484 & 5.8 \\
\hline
\end{tabular}

Table 1. Maximum detected in the UV-vis spectra for the different formulations and their correlation with the amount of polymeric units calculated according to Ahl et al. [19].

DMPC lipids with the addition of DOTAP, SA, or $\mathrm{MCl}$ as $C L$ in the ratio 1:1:0.2 (DMPC:DC8,9PC:CL). When polymeric units are completely formed, after being subjected to 20 polymerization cycles [9], the polymer backbone shows strong absorbance in the visible region of the spectrum [11] and the degree of polymerization of the membrane is related to both the magnitude and the wavelength of visible absorbance peaks [7, 10]. A scheme of the polymer formed is shown in Fig. 1.

It has been previously reported that the use of polymerizable lipids in different liposomal formulations improves system stability after polymerization [18-21]. In the particular case of DC8,9PC, a photopolymerizable lipid, it has been demonstrated that systems containing this particular lipid present enhanced stability after polymerization compared with the same nonpolymerized system in different media [7]. Moreover, polymerization led to a surface modification in such a way that less bovine serum albumin (BSA) was bound compared with the nonpolymerized system [9]. Although it has been demonstrated that polymerization does not lead to an increase in the system's cytotoxicity in vitro, little is known about system toxicity in vivo, particularly when administered directly into lungs.

The maximum absorbance wavelength depends on the number of polymer units electronically coupled. Absorbance around $480 \mathrm{~nm}$ corresponds to shorter polymers and absorbance around $520 \mathrm{~nm}$ to longer conjugation of cross-bridges formed between linear polymers through intra- and inter-molecular C-chains [10, 19]. According to Ahl et al. [19], the amount of polymeric units can be calculated from the maxima detected in the

Xisto/Temprana/Martini/Silva/Abreu/Silva/Crosseti/Rocco/del Valle Alonso/Morales 


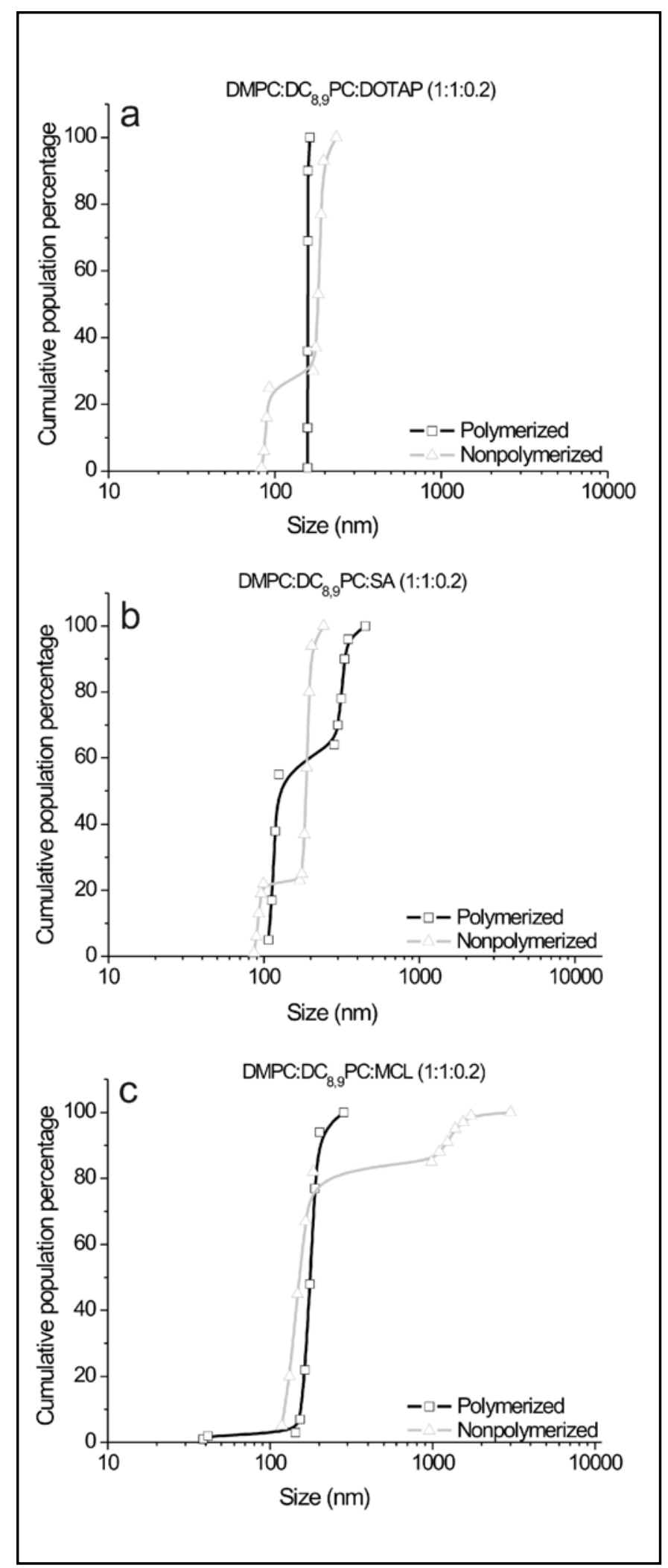

Fig. 2. Cumulative liposome population percentage as a function of size of polymerized and nonpolymerized DMPC:DC8,9PC:DOTAP 1:1:0.2 (a), DMPC:DC8,9PC:SA 1:1:0.2 (b), DMPC:DC8,9PC:MCl 1:1:0.2 (c). Size is presented on a logarithmic scale, and each symbol represents the size obtained for the denoted liposomal population percentage.

The Impact of Lipopolymeric Vectors on Lung Morphofunction

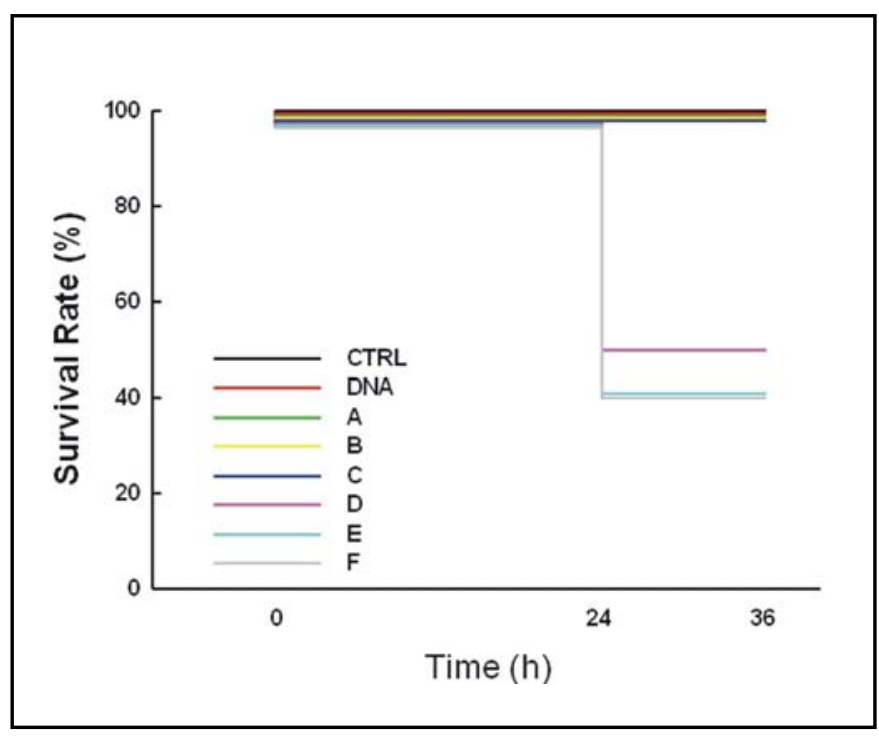

Fig. 3. Kaplan-Meier survival curves for all animals. CTRL, control animal; DNA, animal instilled with plasmid DNA; A, B, $\mathrm{C}, \mathrm{D}, \mathrm{E}, \mathrm{F}$, animal groups instilled with different polymer cationic vectors with plasmid DNA.

UV-vis spectra. Table 1 shows the maxima observed for each system and the corresponding amount of polymeric units.

As can be seen from the values listed in Table 1, the addition of CL does not seem to affect the length of the polymeric units generated, each consisting of about 6-9 units. The 3 formulations were found to be equivalent for the length of polymer generated.

On the other hand, an important parameter to be considered is the size of the vesicles obtained, whether they are polymerized or not. To this end, measurements were performed using dynamic light scattering. Fig. 2 shows the results obtained for the different formulations and conditions.

The graphs shown in Fig. 2 are very useful for studying the different population sizes in the prepared sample. As can be seen in Fig. 2 for DMPC:DC 8,9PC:DOTAP $\quad(1: 1: 0.2) \quad$ and DMPC:DC 8,9PC:SA (1:1:0.2) (Fig. 2a and b, respectively), no significant differences in sizes were found between polymerized and nonpolymerized vesicles, and the sizes of the whole liposome population were between 100 and $1000 \mathrm{~nm}$. In the case of DMPC:DC8,9PC:MCl (1:1:0.2), the polymerized sample had a similar behavior to those described before, but the nonpolymerized sample presented a population of around $20 \%$ with sizes between 1000 and $5000 \mathrm{~nm}$ (see Fig. 2c). 


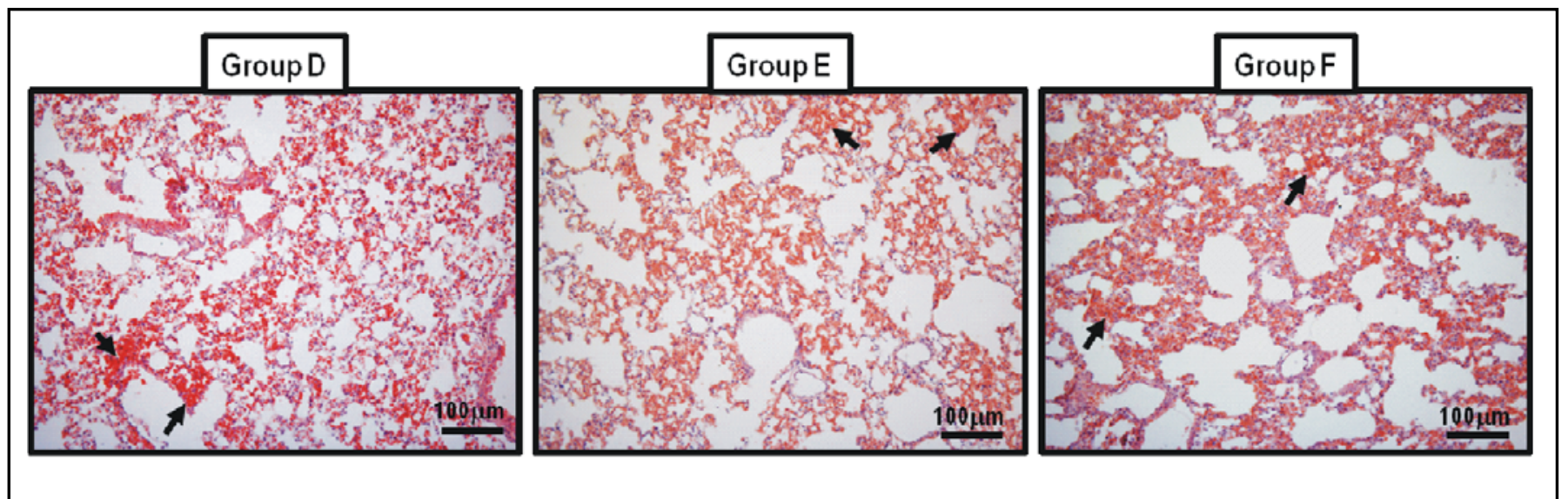

Fig. 4. Photomicrographs of lung parenchyma from groups D, E, and F stained with hematoxylin-eosin. Note the presence of hemorrhage (arrows) associated with areas of alveolar collapse.

\begin{tabular}{lcrrr}
\hline Groups & $E_{\mathrm{st}, \mathrm{L}}\left(\mathrm{cmH}_{2} \mathrm{O} / \mathrm{ml}\right)$ & $\Delta P_{1, \mathrm{~L}}\left(\mathrm{cmH}_{2} \mathrm{O}\right)$ & $\Delta P_{2, \mathrm{~L}}\left(\mathrm{cmH}_{2} \mathrm{O}\right)$ & $\Delta P_{\text {tot, }}\left(\mathrm{cmH}_{2} \mathrm{O}\right)$ \\
\hline CTRL & $31.4 \pm 2.8$ & $0.90 \pm 0.10$ & $0.90 \pm 0.07$ & $1.76 \pm 0.12$ \\
DNA & $33.2 \pm 2.2$ & $0.92 \pm 0.08$ & $0.80 \pm 0.03$ & $1.73 \pm 0.08$ \\
A & $26.2 \pm 1.5$ & $0.90 \pm 0.01$ & $0.77 \pm 0.03$ & $1.68 \pm 0.02$ \\
B & $32.5 \pm 2.2$ & $0.88 \pm 0.01$ & $0.80 \pm 0.02$ & $1.68 \pm 0.02$ \\
C & $31.6 \pm 4.0$ & $0.78 \pm 0.03$ & $0.90 \pm 0.05$ & $1.68 \pm 0.02$ \\
D & $29.6 \pm 3.7$ & $1.03 \pm 0.07$ & $0.88 \pm 0.04$ & $1.91 \pm 0.10$ \\
E & $25.2 \pm 1.1$ & $1.01 \pm 0.01$ & $0.74 \pm 0.03$ & $1.75 \pm 0.04$ \\
F & $24.2 \pm 3.5$ & $0.96 \pm 0.02$ & $0.67 \pm 0.09$ & $1.64 \pm 0.10$ \\
\hline
\end{tabular}

Table 2. Lung mechanics. Values are means $\left( \pm\right.$ SEM) of 6 animals per group. $E_{\text {st. }}$, lung static elastance; $\Delta P_{1, \mathrm{~L}}$, resistive pressure; $\Delta P_{2, \mathrm{~L}}$, viscoelastic pressure; $\Delta P_{\text {tot, }}=\Delta P_{1, \mathrm{~L}}+\Delta P_{2, \mathrm{~L}} ; \mathrm{CTRL}$, control animal; DNA, animal instilled with plasmid DNA; A, B, C, D, E, F, animal groups instilled with different polymer cationic vectors with plasmid DNA.

The second step was to evaluate the survival rate, the lung function and inflammation, and DNA delivery. Thus, the animals underwent intratracheal instillation and these parameters were analyzed $24 \mathrm{~h}$ later.

Fig. 3 shows the survival rate of the animal groups. The survival rate was $100 \%$ for all groups until $24 \mathrm{~h}$. After $24 \mathrm{~h}$ the survival rate was $50 \%$ in group D, $40 \%$ in groups $\mathrm{E}$ and $\mathrm{F}$, and $100 \%$ in the CTRL, DNA, A, $\mathrm{B}$ and $\mathrm{C}$ groups (Fig. 3). Animals from groups D, E, and $\mathrm{F}$ that died showed lung capillaritis (Fig. 4). The features of pulmonary capillaritis included capillary wall necrosis with neutrophil infiltration, interstitial erythrocytes, and interalveolar septal capillary occlusion by fibrin thrombi [22]. This result was in agreement with Freimark et al. [23] who observed cytokine production and cellular influx in the airway after intratracheal instillation of plasmid/lipid complex. Moreover, the intratracheal administration of cationic liposomes yielded an inflammatory response that might be associated with the release of reactive oxygen intermediates resulting in pulmonary toxicity [24]. Animals from groups D, E, and F that died presented greater inflammatory processes with neutrophil infiltration and areas of hemorrhage (Fig. 4).

In the present study, pulmonary mechanics were analyzed using the end-inflation occlusion method in surviving animals from the CTRL, DNA, A, B, C, D, $\mathrm{E}$, and $\mathrm{F}$ groups. This method allows the analysis of lung resistive and viscoelastic pressures, and static elastance. $E_{\mathrm{st}, \mathrm{L}}, \Delta P_{1, \mathrm{~L}}, \Delta P_{2, \mathrm{~L}}$ and $\Delta P_{\text {tot, } \mathrm{L}}$ were similar in all groups (Table 2).

To evaluate lung inflammation we analyzed

Xisto/Temprana/Martini/Silva/Abreu/Silva/Crosseti/Rocco/del Valle Alonso/Morales 


\begin{tabular}{lrrrrrrrr}
\hline Groups & CTRL & DNA & A & B & C & D & E & F \\
\hline Normal (\%) & $86.2 \pm 0.4$ & $88.7 \pm 0.4$ & $83.2 \pm 1.9$ & $86.2 \pm 2.6$ & $88.6 \pm 2.0$ & $88.2 \pm 0.9$ & $83.7 \pm 0.7$ & $84.4 \pm 6.2$ \\
Collapse (\%) & $13.8 \pm 0.3$ & $11.3 \pm 0.8$ & $16.8 \pm 1.1$ & $13.8 \pm 0.7$ & $11.4 \pm 1.4$ & $11.8 \pm 0.7$ & $16.3 \pm 0.69$ & $15.6 \pm 6.2$ \\
PMN (\%) & $8.9 \pm 1.3$ & $7.5 \pm 1.5$ & $6.8 \pm 0.2$ & $8.2 \pm 1.1$ & $8.6 \pm 0.3$ & $8.1 \pm 0.7$ & $5.8 \pm 0.6$ & $8.4 \pm 1.3$ \\
MN (\%) & $39.2 \pm 2.0$ & $39.1 \pm 2.7$ & $46.5 \pm 0.5$ & $41.4 \pm 1.9$ & $40.2 \pm 2.6$ & $43.7 \pm 0.5$ & $38.3 \pm 0.3$ & $45.5 \pm 1.1$ \\
\hline
\end{tabular}

Table 3. Lung morphometry. Values are means $( \pm \mathrm{SEM})$ of 6 animals per group. Data were gathered from ten random, noncoincident fields per mouse. Normal: normal alveoli, Collapse: collapsed alveoli, PMN: polymorphonuclear, MN: mononuclear. CTRL, control animal; DNA, animal instilled with plasmid DNA; A, B, C, D, E, F, animal groups instilled with different polymer cationic vectors with plasmid DNA.

the fractional area of alveolar collapse and lung cellularity and there was no difference among the groups for these parameters (Table 3).

The lipopolymers were administered intratracheally to study the effect of this particular system. As expected, pDsRed2-N1 plasmid was detected through real-time PCR in the lungs in all groups of mice that were administered DNA (data not shown).

In conclusion, intratracheal instillation of polymerized particles seems to be safe compared with nonpolymerized formulations since it showed higher survival rate and did not induce lung inflammation. Thus, this polymerized particle may be an option for gene/drug delivery in the future.

\section{References}

1 Griesenbach U, Alton EW: Gene transfer to the lung: lessons learned from more than 2 decades of CF gene therapy. Adv Drug Deliv Rev 2009;61:128-139.

-2 Geiger J, Aneja MK, Rudolph C: Vectors for pulmonary gene therapy. Int $\mathrm{J}$ Pharm 2010;390:84-88.

-3 Ilarduya CT, Sun Y, Düzgünes N: Gene delivery by lipoplexes and polyplexes. Eur J Pharm Sci 2010;40:159-170.

-4 Simões S, Pires P, Düzgünes N, Pedroso de Lima MC: Cationic liposomes as gene transfer vectors: barriers to successful application in gene therapy. Curr Opin Mol Ther 1999;1:147-157.

$\checkmark 5$ Adler AF, Leong KW: Emerging links between surface nanotechnology and endocytosis: Impact on nonviral gene delivery. Nano Today 2010;5:553-569.

-6 Yavlovich A, Singh A, Tarasov S, Capala J, Blumenthal R, Puri A: Design of liposomes containing photopolymerizable phospholipids for triggered release of contents. J Therm Anal Calorim 2009;98:97-104.

7 Alonso-Romanowski S, Chiaramoni NS, Lioy VS, Gargini RA, Viera LI, Taira MC: Characterization of diacetylenic liposomes as carriers for oral vaccines. Chem Phys Lipids 2003;122:191-203.
Bangham AD, Standish MM, Watkins JC: Diffusion of univalent ions across lamellae of swollen phospholipids. J Mol Biol 1965;13:238-252.

Temprana CF, Amor MS, Femia AL, Gasparri J, Taira MC, dell Valle Alonso S: Ultraviolet irradiation of diacetylenic liposomes as a strategy to improve size stability and to alter protein binding without cytotoxicity enhancement. J Liposome Res 2011;21:141-150.

Johnston DS, McLean LR, Whittam MA, Clarke AD, Chapman D: Spectra and physical properties of liposomes and monolayers of polymerizable phospholipids containing diacetylene groups in one or both acyl chains. Biochemistry 1983;22:3194-3202. Albrecht O, Johnston DS, Villaverde C, Chapman DS: Stable biomembrane surfaces formed by phospholipids polymers. Biochim Biophys Acta 1982;687:165-169.

12 Bartlett GR: Phosphorus assay in column chromatography. J BiolChem 1959;234:466-468.

Burburan SM, Xisto DG, Ferreira HC, Riva D, Carvalho GM, Zin WA, Rocco PRM: Lung mechanics and histology during sevoflurane anesthesia in a model of chronic allergic asthma. Anesth Analg 2007;104:631-637.
Bates JH, Ludwig MS, Sly PD, Brown K, Martin JG, Fredberg JJ: Interrupter resistance elucidated by alveolar pressure measurement in open-chest normal dogs. J Appl Physiol 1988;65:408-414.

15 Weibel ER: Morphometry: stereological theory and practical methods; In Gil J (ed): Models of Lung Disease Microscopy and Structural Methods. New York, Marcel Dekker, 1990, pp 199-247.

16 Hsia CC, Hyde DM, Ochs M, Weibel ER: An official research policy statement of the American Thoracic Society / European Respiratory Society: standards for quantitative assessment of lung structure. Am J Respir Crit Care Med 2010;181:394-418.

17 Xisto DG, Farias LL, Ferreira HC, Picanco MR, Amitrano D, Lapa E Silva JR, Negri EM, Mauad T, Carnielli D, Silva LFF, Capelozzi VL, Faffe DS, Zin WA, Rocco PRM: Lung parenchyma remodeling in a murine model of chronic allergic inflammation. Am J Respir Crit Care Med 2005;171:829-837.

Blume A: Phase transition of polymerizable phospholipids. Chem Phys Lipids 1991;57:253-273.

Ahl PL, Price R, Smuda J, Gaber BP, Singh A: Insertion of bacteriorhodopsin into polymerized diacetylenic phosphatidylcholine bilayers. Biochim Biophys Acta 1990;1028:141-153. 
-20 Freeman FJ, Hayward JA, Chapman D: Permeability studies on liposomes formed from polymerisable diacetylenic phospholipids and their potential applications as drug delivery systems. Biochim Biophys Acta 1987;924:341351 .

-2 1 Hayward JA, Johnston DS, Chapman D: Polymeric phospholipids as new biomaterials. Ann N Y Acad Sci 1985;446:267-281
22 Franks TJ, Koss MN: Pulmonary capillaritis. Curr Opin Pulm Med 2000;6:430-435.

3 Freimark BD, Blezinger HP, Florack VJ, Nordstrom JL, Long SD, Deshpande DS, Nochumson S, Petrak KL: Cationic lipids enhance cytokine and cell influx levels in the lung following administration of plasmid: cationic lipid complexes. J Immunol 1998;160:4580-4586.
Dokka S, Toledo D, Shi X, Castranova V, Rojanasakul Y: Oxygen radical-mediated pulmonary toxicity induced by some cationic liposomes. Pharm Res 2000; $17: 521-525$ 